\title{
Serum Levels of Selected Th17 and Th22 Cytokines in Psoriatic Patients
}

\section{Anna Michalak-Stoma, Joanna Bartosińska, Małgorzata Kowal, Maria Juszkiewicz-Borowiec, Agnieszka Gerkowicz, and Grażyna Chodorowska}

Chair and Department of Dermatology, Venereology and Pediatric Dermatology, Medical University of Lublin, ul. Radziwiłłowska 13, 20-080 Lublin, Poland

Correspondence should be addressed to Anna Michalak-Stoma; annamichalak@wp.pl

Received 28 June 2013; Revised 7 October 2013; Accepted 8 October 2013

Academic Editor: Esperanza Ortega

Copyright (C) 2013 Anna Michalak-Stoma et al. This is an open access article distributed under the Creative Commons Attribution License, which permits unrestricted use, distribution, and reproduction in any medium, provided the original work is properly cited.

Introduction. Psoriasis is a T cell-mediated inflammatory disease in which pathogenesis Thelper (Th) lymphocytes (Thl, Thl7, and Th22) play an important role. The aim of the study was to assess the serum levels of some cytokines involved in the Th17 and Th22 responses in psoriatic patients. Material and Methods. The study comprised 60 psoriatic patients and 30 healthy controls. In the serum collected from psoriatic patients and healthy controls, the concentrations of IL-6, IL-12, IL-17, IL-20, IL-22, and IL-23 were examined with ELISA kits. Severity of psoriatic skin lesions was assessed by means of PASI, BSA, and PGA scores. Results. IL-6, IL-20, and IL-22 concentrations were significantly higher in psoriatic patients in comparison with the control group. The positive correlations between the concentrations of IL-22 and IL-20 and severity of psoriasis assessed with PASI and BSA scores as well as IL17 and PASI score were found. There was also a positive correlation between IL-23 and IL-17 concentrations. Conclusions. Results of the conducted studies suggest that Th22 response may contribute to the skin and systemic inflammatory disease in psoriasis. It seems that early identification of soluble biomarkers and initiation of well-matched treatment may prevent exacerbation and progression of psoriasis.

\section{Introduction}

The knowledge about the role of cytokines in psoriasis has developed in the last several years. Initially, only Th1 cells and cytokines secreted by these cells, like TNF- $\alpha$, IFN- $\gamma$, and IL-2, have been associated with the development and maintenance of chronic inflammatory diseases, such as psoriasis. Th1 cells differentiate from naive CD4+ cells in the presence of IL-12, IL-18, and IFN $\alpha$ and $\gamma$. It is well known that Th1 cytokines have strong inflammatory effects in activating macrophage, neutrophil, and CD8+ cytotoxic T cells [1].

In the 1990s, Th17 cells were described as a new T-cell population that produces IL-17, IL-6, IL-21, IL-22, and TNF [2]. Transforming growth factor (TGF)- $\beta 1$, IL-6, IL-23, and IL-15 stimulated initial Th17 differentiation from naive T cells [3]. TGF- $\beta 1$ is secreted by activated T cells and it initiates $\mathrm{T}$ cell and fibroblast activation, as well as angiogenesis and neovascularization [3-7]. IL-6, secreted by macrophages, endothelial cells, and epithelial cells, is responsible for augmentation of keratinocyte hyperplasia and invasion of macrophages and T cells $[3,8]$. IL-15, produced by monocytes, macrophages, DCs, and T cells, can appear to induce angiogenesis, immune cell recruitment, and activation of keratinocytes $[4,9,10]$. Once the Th17 phenotype is achieved, IL-23 maintains a cellular Th17-polarisation [11]. Cytokines produced by Th17 cells were found to initiate acanthosis, hyperkeratosis, and parakeratosis. Th17 cells demonstrated involvement in neutrophil and monocyte chemotaxis, T-cell migration and activation, and neovascularization [3].

Th 22 cells have been recently described as inflammatory CD4+ T cells that produce cytokines such as IL-22, IL-26, and IL-13 of which IL-22 is the most important functional cytokine. Th22 cells do not express IL-17A or IFN- $\gamma$ [12-15]. Recent studies indicate that IL- 6 and TNF- $\alpha$, along with the help of plasmacytoid dendritic cells, can promote the Th22 phenotype $[14,16]$. 


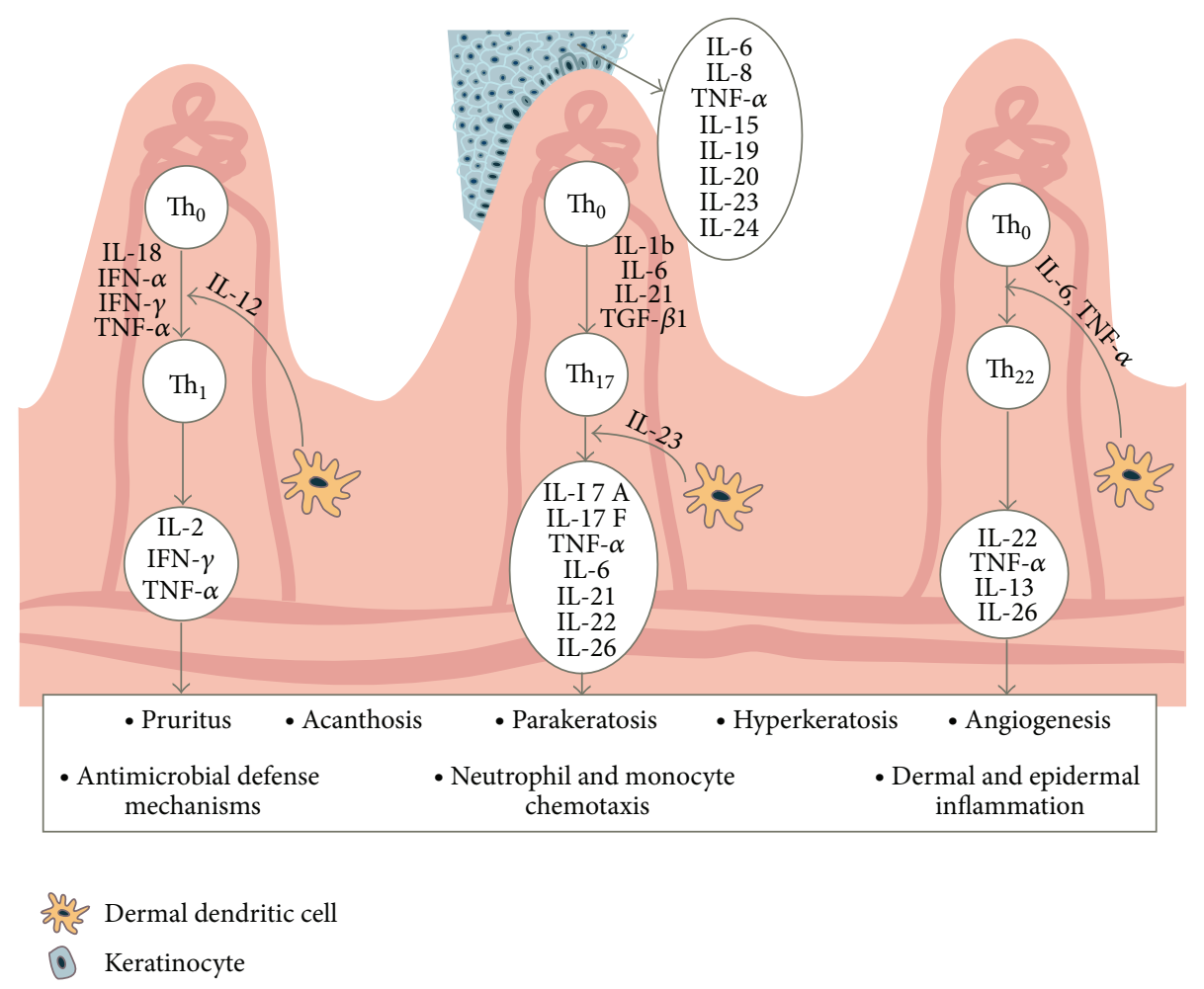

FIgURE 1: Th1, Th17, and Th22 cytokines in the pathogenesis of psoriasis.

IL-20 resembles IL-22 structurally and belongs to the same cytokine family. IL-22 can stimulate IL-20 production in keratinocytes [15].

The differentiation of main three $\mathrm{T}$ cell subsets involved in the pathogenesis of psoriasis, as well as Th1, Th17, and Th22 cytokine production are illustrated in Figure 1.

The aim of the study was to assess the serum levels of some cytokines involved in the Th17 and Th22 responses in psoriatic patients.

\section{Materials and Methods}

2.1. Characteristics of the Studied Group. The study comprised 60 psoriatic patients, 50 males $(83.33 \%)$ and 10 females (16.67\%), as well as 30 healthy controls. The studied patients' age was between 18 and 69 years, $45.6 \pm 13.2$ years on average. The history of the disease was from 1 to 45 years, $18.7 \pm$ 11.5 years on average. Thirty-seven patients $(61.67 \%)$ suffered from persistent psoriatic skin lesions. Thirty-four of the studied patients (40\%) reported two psoriasis exacerbations a year, whereas 9 persons (15\%) observed as many as 4 exacerbations a year.

2.2. Assessment of Psoriasis Severity. The skin lesions severity was assessed with the use of Psoriasis Area and Severity Index (PASI), Body Surface Area (BSA), and Physician Global Assessment (PGA) scores. The PASI value in the studied group was from 4.8 to 64.2 and $15.7 \pm 9.7$ on average. The BSA value was in the range of $9.0-96.9 \%$ and $31.4 \pm 18.2$ on average. The PGA score was 3 in 24 individuals (40\%), 4 in another 24 individuals (40\%), and 5 in 12 individuals (20\%).

2.3. Assessment of Cytokine Serum Concentrations in the Psoriatic Patients and the Controls. Blood samples were collected from psoriatic patients and controls and were centrifuged for 15 minutes at $1000 \times \mathrm{g}$. Then, serum samples were subdivided into small aliquots to be stored at $-80^{\circ} \mathrm{C}$ until tested for cytokine levels. ELISA kits were used to determine IL-6, IL12, IL-17, IL-20, IL-22, and IL-23 (R\&D Systems, Minneapolis, MN, USA) serum levels, according to the manufacturer's instructions.

2.4. Statistical Analyses. Statistical analyses were performed using STATISTICA software. Continuous variables were presented as mean \pm standard deviation, while categorical variables were presented as absolute and relative frequencies. Mann-Whitney's $U$ test was used to compare continuous data between the studied and control groups. Pearson's correlation coefficient was used in correlation analyses. 0.05 significant level was assumed in statistical tests.

\section{Results and Discussion}

3.1. Comparison of the Selected Cytokine Serum Concentrations in the Psoriatic Patients and the Control Group. The statistical analyses of the conducted study results revealed significantly higher serum levels of IL-6, IL-20, and IL-23 in psoriatic patients comparing to healthy controls (Table 1 and Figure 2). 

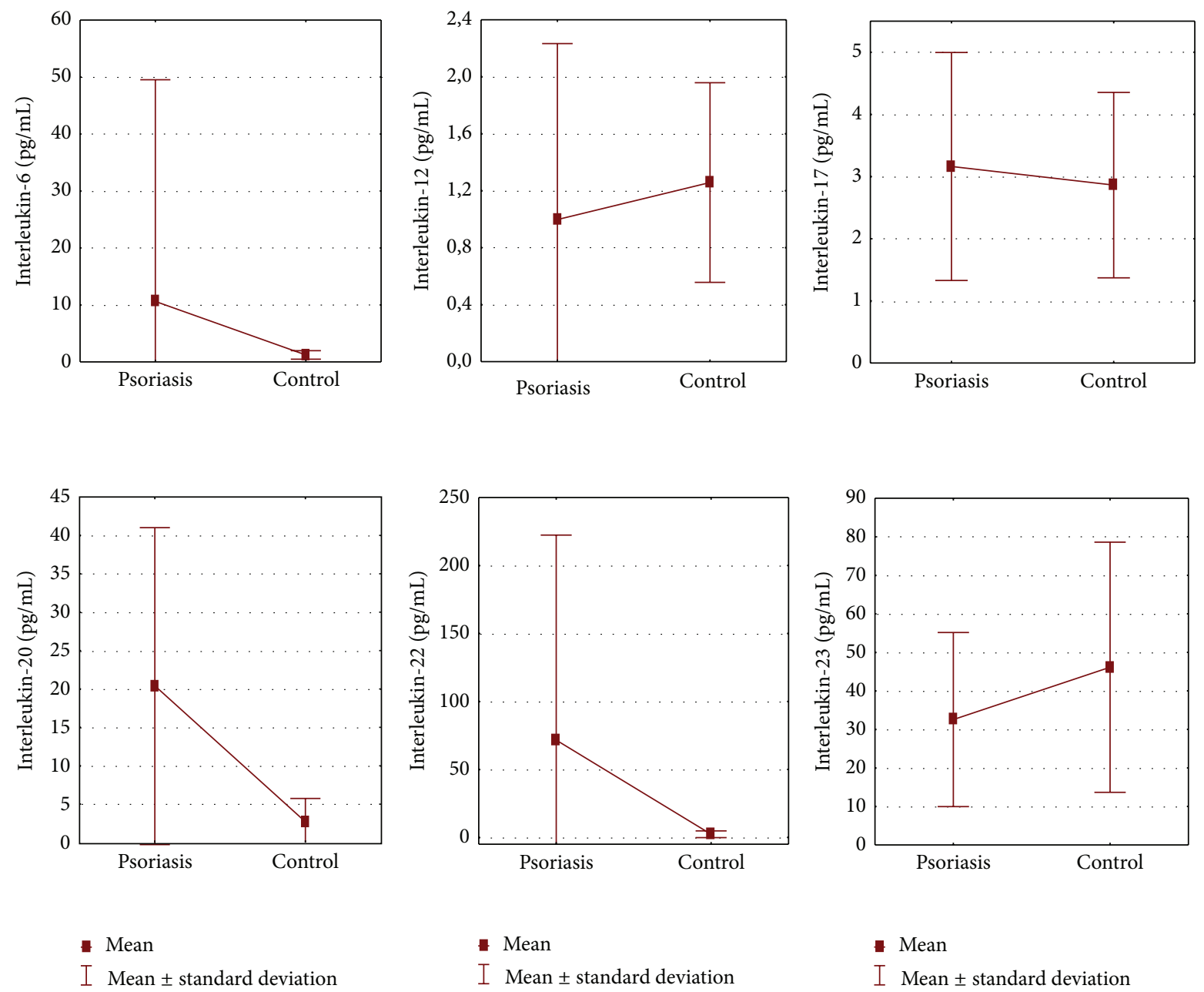

FIGURE 2: Comparing of selected cytokine serum concentrations in the psoriatic patients and the control group.

Significant correlations between IL-20, IL-22, IL-17, and psoriasis severity were observed. No significant correlations were found between the concentrations of the studied cytokines and the sex, age, or psoriasis duration in the studied patients $(P>0.05)$.

3.1.1. Interleukin-6 (IL-6). Significantly higher IL-6 values were found in the psoriatic patients in comparison to the control group $(P<0.001)$.

IL-6 contributes to the Th17 cell line's involvement in numerous processes of inflammation and autoimmunity by preventing the proliferation of T regulatory cells [3]. IL-17 can induce fibroblasts to produce IL-6 potentially activating a positive feedback loop that strengthens Th17 inflammation [12].

Elevated serum IL-6 was observed in psoriatic patients in many studies [17-23]. Dowlatshahi et al. analyzed 78 studies comparing the serum inflammatory markers, including IL-6, in psoriasis with healthy controls [21]. The study showed that the standardized mean differences were higher in psoriatic patients compared to healthy controls for IL-6. Elevated serum IL-6 appears to be associated with greater psoriasis severity $[18,21,24]$. It was shown that IL- 6 might be the biomarker differentiating psoriasis arthritis from psoriasis without joint involvement $[19,22]$.

3.1.2. Interleukin-20 (IL-20). Significantly higher IL-20 values were found in the psoriatic patients in comparison to the control group $(P<0.001)$. A significant positive correlation between the IL-20 concentrations and psoriasis severity measured by the PASI was detected $(P<0.001 ; r=0.698)$.

IL-20 is produced by keratinocytes in the presence of IL22 , TNF- $\alpha$, and IL-17 but not IFN- $\gamma$ or IL-20 itself $[15,25]$. It can also be produced by stimulated monocytes and DCs [26-28]. IL-20 can play an important role in the later effector phase of psoriasis pathogenesis, in which it inhibits the terminal differentiation, increases antimicrobial competence, and production of chemokines for neutrophils in keratinocytes $[25,29]$.

There are not many studies concerning IL-20 serum level, but increased levels of IL-20 were noted in lesional skin as 
TABLE 1: The selected cytokine serum concentrations in the psoriatic patients and the control group.

\begin{tabular}{lccc}
\hline Cytokine & Psoriasis & Control & $P$ \\
\hline IL-6 $(\mathrm{pg} / \mathrm{mL})$ & $10.622 \pm 38.906$ & $1.226 \pm 0.745$ & $<0.001$ \\
IL-12 $(\mathrm{pg} / \mathrm{mL})$ & $0.997 \pm 1.236$ & $1.257 \pm 0.701$ & 0.075 \\
IL-17 $(\mathrm{pg} / \mathrm{mL})$ & $3.163 \pm 1.834$ & $2.863 \pm 1.492$ & 0.684 \\
IL-20 $(\mathrm{pg} / \mathrm{mL})$ & $20.418 \pm 20.587$ & $2.703 \pm 3.043$ & $<0.001$ \\
IL-22 $(\mathrm{pg} / \mathrm{mL})$ & $71.600 \pm 150.759$ & $2.358 \pm 2.486$ & $<0.001$ \\
IL-23 $(\mathrm{pg} / \mathrm{mL})$ & $32.553 \pm 22.599$ & $46.130 \pm 32.476$ & 0.094 \\
\hline
\end{tabular}

well as in the blood in psoriatic patients [25]. As in our study, IL-20 serum levels correlated with PASI scores [25].

3.1.3. Interleukin-22 (IL-22). A significantly higher increase in IL-22 was observed in psoriatic patients in comparison with the healthy controls $(P<0.001)$. A significant positive correlation was found between the IL-22 concentration and psoriasis severity measured by both the PASI and BSA score; that is, $P<0.001 ; r=0.557$ and $P<0.001 ; r=0.559$, respectively.

IL-22 is a member of the IL-10 cytokines family and is mainly produced by Th17, Th22, and mucosal NK cells [3032]. IL-22 upregulates keratinocyte proliferation and migration, inhibits keratinocyte differentiation by downregulating a variety of genes as filaggrin and involucrin genes [33, 34], and augments the expression of inflammatory molecules by keratinocytes, which leads to an increase in skin thickness in vitro and in vivo [35-37]. IL-22 increased the expression of the hBD-2 and hBD-3 in human keratinocytes and MMP1 and MMP3 in the skin [38-40].

In psoriasis, IL-22 is overexpressed most probably as a result of upregulated IL-23 and IL-6 levels [12, 41, 42]. IL-22 levels in plasma correlated with psoriasis severity [31]. The treatment with TNF inhibitor (etanercept) reduced serum levels of IL-17 and IL-22 [43].

3.1.4. Interleukin-12 (IL-12) and Interleukin-23 (IL-23). No significant differences were found in the IL-12 and IL-23 concentrations between the psoriatic patients and control group $(P>0.05)$.

IL-23 together with IL-12 belongs to the IL-12 family and are both structurally related; IL-12 is formed by the p40 and p35 subunits; IL-23 consists of p40 and p19 subunits [44, 45].

Although both IL-12 and IL-23 are present in psoriasis, studies support that IL-23, rather than IL-12, is crucial during the pathogenesis of psoriasis. IL-23 is overexpressed in psoriasis lesional skin, as shown for example, by increased p40 and p19 mRNA levels but not always p35 [46-54]. IL23 is overproduced by dermal dendritic cells $[48,53]$ and keratinocytes [51] in lesional psoriatic skin.

IL-23 has the influence on sustenance and amplification of the chronic inflammation in psoriasis [55]. IL-23 level decreases after psoriasis therapy [51]. On the other hand, most recent reports show no increased expression of the IL-12 in psoriasis [3, 49, 52, 53]. Statistically significant differences in serum IL-12 level have been found in psoriatic patients comparing to healthy controls $[20,56]$. However, there are no significant studies comparing the serum levels of IL-23 in psoriatic patients and controls.

3.1.5. Interleukin-17 (IL-17). No significant differences were found in the serum IL-17 concentrations between the psoriatic patients and control group $(P>0.05)$. A significant positive correlation between the IL-17 concentrations and psoriasis severity measured by the PASI was detected $(P<$ $0.05 ; r=0.277)$.

IL-17 (IL-17A) is a member of a newly identified cytokine family comprising IL-17A, IL-17B, IL-17C, IL-17D, IL-17E (IL-25), and IL-17F. IL-17 and IL-17F have a proinflammatory activity inducing the expression of proinflammatory cytokines, colony-stimulating factors, and chemokines from dendritic cells, neutrophils, T cells, monocyte/macrophages, and epithelial cells [11, 44]. IL-17A and IL-17F can mobilize, recruit, and activate neutrophils $[44,57]$.

IL-17 is undetectable in normal skin, and biological therapy that inhibits Th17 pathways results in reduced expression of IL-17 and IL-23 and improved disease outcomes [11, 24, 39]. Th17 cells and the cytokines produced by these cells are found in increased levels within skin affected by psoriasis [31, 47$49,58-60]$. Statistically significant differences in serum IL$17 \mathrm{~A}$ level have been found in psoriatic patients comparing to healthy controls [20]. IL-17 serum levels correlated with the psoriasis area and severity index (PASI) [20].

3.2. Analysis of Correlations between the Determined Cytokine Concentrations in Psoriatic Patients. In addition, an analysis of mutual correlations between the concentrations of selected cytokines in the psoriatic patients was conducted. A significant positive correlation between the IL-23 and IL-17 values was found $(P<0.05 ; r=0.271)$. An increase in the IL23 concentration was accompanied by an increase in the IL-17 concentration. In previous studies, it was found that interaction of IL-23 with its receptor on Th17 cells stimulates the production of IL-17 and other related proinflammatory cytokines activates NK cells and regulates antibody production $[1,3,44]$.

\section{Conclusions}

We believe that the results of our study confirm involvement of Th17 and Th22 cytokines in psoriasis pathogenesis. Elevated IL-22 level without increase of IL-17 level may suggest that Th22 role is more significant in the inflammatory process of psoriasis. Very high concentrations of IL-22 in the patients' 
serum can be connected with intensive IL-6 stimulation. IL22 and IL-20 itself induce production of IL-20, which is elevated in our study. It seems that IL-6, which initiates Th17 and Th22 pathways in psoriasis, may be helpful in the clinical practice as a soluble biomarker of the disease activity and its prognosis. The development of new therapeutical strategies targeting the initial step of cytokine network activation, for example, IL-6, may reduce the next events of inflammatory reactions and prevent the psoriasis exacerbation and systemic complications. Furthermore, serum levels of IL-20, IL-22, and IL-17, which correlated with the clinical severity and activity of psoriasis, may be objective parameters of successful treatment and may be used in the followup.

$\begin{array}{ll}\text { Abbreviations } \\ \text { BSA: } & \text { Body Surface Area } \\ \text { ELISA: } & \text { Enzyme-linked immunosorbent assay } \\ \text { hBD: } & \text { Human beta-defensin } \\ \text { IFN: } & \text { Interferon } \\ \text { IL: } & \text { Interleukin } \\ \text { MMP: } & \text { Matrix metalloproteinase } \\ \text { mRNA: } & \text { Messenger ribonucleic acid } \\ \text { NK: } & \text { Natural killer } \\ \text { PASI: } & \text { Psoriasis Area and Severity Index } \\ \text { PGA: } & \text { Physician Global Assessment } \\ \text { TGF: } & \text { Transforming growth factor } \\ \text { Th: } & \text { T helper } \\ \text { TNF: } & \text { Tumor necrosis factor. }\end{array}$

\section{Acknowledgment}

This work was supported by a Grant DS164.

\section{References}

[1] A. Michalak-Stoma, A. Pietrzak, J. C. Szepietowski, A. Zalewska-Janowska, T. Paszkowski, and G. Chodorowska, "Cytokine network in psoriasis revisited," European Cytokine Network, vol. 22, no. 4, pp. 160-168, 2011.

[2] P. Miossec, "IL-17 and Th17 cells in human inflammatory diseases," Microbes and Infection, vol. 11, no. 5, pp. 625-630, 2009.

[3] A. Asarch, O. Barak, D. S. Loo, and A. B. Gottlieb, "Th17 cells: a new paradigm for cutaneous inflammation," Journal of Dermatological Treatment, vol. 19, no. 5, pp. 259-266, 2008.

[4] A. Asarch, O. Barak, D. S. Loo, and A. B. Gottlieb, "Th17 cells: a new therapeutic target in inflammatory dermatoses," Journal of Dermatological Treatment, vol. 19, no. 6, pp. 318-326, 2008.

[5] W. Baran, J. C. Szepietowski, G. Mazur, and E. Baran, “TGF- $\beta 1$ gene polymorphism in psoriasis vulgaris," Cytokine, vol. 38, no. 1, pp. 8-11, 2007.

[6] P. Nockowski, J. C. Szepietowski, M. Ziarkiewicz, and E. Baran, "Serum concentrations of transforming growth factor beta 1 in patients with psoriasis vulgaris," Acta Dermatovenerologica Croatica, vol. 12, no. 1, pp. 2-6, 2004.

[7] M. J. McGeachy and D. J. Cua, "T cells doing it for themselves: TGFbeta regulation of Th1 and Th17 cells," Immunity, vol. 26, no. 5, pp. 547-549, 2007.

[8] R. M. Grossman, J. Krueger, D. Yourish et al., "Interleukin 6 is expressed in high levels of psoriatic skin and stimulates proliferation of cultured human keratinocytes," Proceedings of the National Academy of Sciences of the United States of America, vol. 86, no. 16, pp. 6367-6371, 1989.

[9] I. B. McInnes and J. A. Gracie, "Interleukin-15: a new cytokine target for the treatment of inflammatory diseases," Current Opinion in Pharmacology, vol. 4, no. 4, pp. 392-397, 2004.

[10] L. S. Villadsen, J. Schuurman, F. Beurskens et al., "Resolution of psoriasis upon blockade of IL-15 biological activity in a xenograft mouse model," The Journal of Clinical Investigation, vol. 112, no. 10, pp. 1571-1580, 2003.

[11] A. W. Armstrong, S. V. Voyles, E. J. Armstrong, E. N. Fuller, and J. C. Rutledge, "A tale of two plaques: convergent mechanisms of T-cell-mediated inflammation in psoriasis and atherosclerosis," Experimental Dermatology, vol. 20, no. 7, pp. 544-549, 2011.

[12] K. E. Nograles, B. Davidovici, and J. G. Krueger, "New insights in the immunologic basis of psoriasis," Seminars in Cutaneous Medicine and Surgery, vol. 29, no. 1, pp. 3-9, 2010.

[13] T. Duhen, R. Geiger, D. Jarrossay, A. Lanzavecchia, and F. Sallusto, "Production of interleukin 22 but not interleukin 17 by a subset of human skin-homing memory T cells," Nature Immunology, vol. 10, no. 8, pp. 857-863, 2009.

[14] Y. Liu, B. Yang, M. Zhou et al., "Memory IL-22-producing CD4 ${ }^{+}$ T cells specific for Candida albicans are present in humans," European Journal of Immunology, vol. 39, no. 6, pp. 1472-1479, 2009.

[15] R. Sabat and K. Wolk, "Research in practice: IL-22 and IL-20: significance for epithelial homeostasis and psoriasis pathogenesis," Journal der Deutschen Dermatologischen Gesellschaft, vol. 9, no. 7, pp. 518-523, 2011.

[16] N. Zhang, H.-F. Pan, and D.-Q. Ye, "Th22 in inflammatory and autoimmune disease: prospects for therapeutic intervention," Molecular and Cellular Biochemistry, vol. 353, no. 1-2, pp. 41-46, 2011.

[17] O. Arican, M. Aral, S. Sasmaz, and P. Ciragil, "Serum levels of TNF- $\alpha$, IFN- $\gamma$, IL-6, IL-8, IL-12, IL-17, and IL-18 in patients with active psoriasis and correlation with disease severity," Mediators of Inflammation, vol. 2005, no. 5, pp. 273-279, 2005.

[18] S. Kaur, K. Zilmer, V. Leping, and M. Zilmer, "Comparative study of systemic inflammatory responses in psoriasis vulgaris and mild to moderate allergic contact dermatitis," Dermatology, vol. 225, pp. 54-61, 2012.

[19] V. Chandran, "Soluble biomarkers may differentiate psoriasis from psoriatic arthritis," The Journal of Rheumatology. Supplement, vol. 89, pp. 65-66, 2012.

[20] H. Takahashi, H. Tsuji, Y. Hashimoto, A. Ishida-Yamamoto, and H. Iizuka, "Serum cytokines and growth factor levels in Japanese patients with psoriasis," Clinical and Experimental Dermatology, vol. 35, no. 6, pp. 645-649, 2010.

[21] E. A. Dowlatshahi, E. A. van der Voort, L. R. Arends, and T. Nijsten, "Markers of systemic inflammation in psoriasis: a systematic review and meta-analysis," British Journal of Dermatology, vol. 169, no. 2, pp. 266-282, 2013.

[22] G.-M. Alenius, C. Eriksson, and S. R. Dahlqvist, "Interleukin-6 and soluble interleukin-2 receptor alpha-markers of inflammation in patients with psoriatic arthritis?" Clinical and Experimental Rheumatology, vol. 27, no. 1, pp. 120-123, 2009.

[23] A. Pietrzak, M. Podhorecka, G. Chodorowska et al., "IL-6 and FAS (CD95) serum level in patients suffering from psoriasis and in relation to the lymphocyte subpopulations," Annales Universitatis Mariae Curie-Sklodowska D, vol. 59, no. 1, pp. 500504, 2004. 
[24] A. T. Pietrzak, A. Zalewska, G. Chodorowska et al., "Cytokines and anticytokines in psoriasis," Clinica Chimica Acta, vol. 394, no. 1-2, pp. 7-21, 2008.

[25] K. Wolk, E. Witte, K. Warszawska et al., “The Th17 cytokine IL22 induces IL-20 production in keratinocytes: a novel immunological cascade with potential relevance in psoriasis," European Journal of Immunology, vol. 39, no. 12, pp. 3570-3581, 2009.

[26] K. Wolk, S. Kunz, K. Asadullah, and R. Sabat, "Cutting edge: immune cells as sources and targets of the IL-10 family members?" Journal of Immunology, vol. 168, no. 11, pp. 5397-5402, 2002.

[27] K. Wolk, K. Witte, E. Witte et al., "Maturing dendritic cells are an important source of IL-29 and IL-20 that may cooperatively increase the innate immunity of keratinocytes," Journal of Leukocyte Biology, vol. 83, no. 5, pp. 1181-1193, 2008.

[28] S. Kunz, K. Wolk, E. Witte et al., "Interleukin (IL)-19, IL-20 and IL-24 are produced by and act on keratinocytes and are distinct from classical ILs," Experimental Dermatology, vol. 15, no. 12, pp. 991-1004, 2006.

[29] K. Wolk, H. S. Haugen, W. Xu et al., "IL-22 and IL-20 are key mediators of the epidermal alterations in psoriasis while IL-17 and IFN- $\gamma$ are not," Journal of Molecular Medicine, vol. 87, no. 5, pp. 523-536, 2009.

[30] S. J. Aujla, P. J. Dubin, and J. K. Kolls, “Th17 cells and mucosal host defense," Seminars in Immunology, vol. 19, no. 6, pp. 377382, 2007.

[31] K. Wolk, E. Witte, E. Wallace et al., "IL-22 regulates the expression of genes responsible for antimicrobial defense, cellular differentiation, and mobility in keratinocytes: a potential role in psoriasis," European Journal of Immunology, vol. 36, no. 5, pp. 1309-1323, 2006.

[32] M. Cella, A. Fuchs, W. Vermi et al., "A human natural killer cell subset provides an innate source of IL-22 for mucosal immunity," Nature, vol. 457, no. 7230, pp. 722-725, 2009.

[33] K. Boniface, F.-X. Bernard, M. Garcia, A. L. Gurney, J.-C. Lecron, and F. Morel, "IL-22 inhibits epidermal differentiation and induces proinflammatory gene expression and migration of human keratinocytes," Journal of Immunology, vol. 174, no. 6, pp. 3695-3702, 2005.

[34] D. Gutowska-Owsiak, A. L. Schaupp, M. Salimi, S. Taylor, and G. S. Ogg, "Interleukin-22 downregulates filaggrin expression and affects expression of profilaggrin processing enzymes," British Journal of Dermatology, vol. 165, no. 3, pp. 492-498, 2011.

[35] Y. Tokura, T. Mori, and R. Hino, "Psoriasis and other Thl7mediated skin diseases," Journal of UOEH, vol. 32, no. 4, pp. 317328, 2010.

[36] S. Eyerich, K. Eyerich, D. Pennino et al., "Th22 cells represent a distinct human $\mathrm{T}$ cell subset involved in epidermal immunity and remodeling," The Journal of Clinical Investigation, vol. 119, no. 12, pp. 3573-3585, 2009.

[37] M. Tohyama, Y. Hanakawa, Y. Shirakata et al., "IL-17 and IL-22 mediate IL-20 subfamily cytokine production in cultured keratinocytes via increased IL-22 receptor expression," European Journal of Immunology, vol. 39, no. 10, pp. 2779-2788, 2009.

[38] K. Wolk and R. Sabat, "Interleukin-22: a novel T- and NKcell derived cytokine that regulates the biology of tissue cells," Cytokine and Growth Factor Reviews, vol. 17, no. 5, pp. 367-380, 2006.

[39] S. J. Aujla and J. K. Kolls, "IL-22: a critical mediator in mucosal host defense," Journal of Molecular Medicine, vol. 87, no. 5, pp. 451-454, 2009.
[40] A. Andoh, Z. Zhang, O. Inatomi et al., "Interleukin-22, a member of the IL-10 subfamily, induces inflammatory responses in colonic subepithelial myofibroblasts," Gastroenterology, vol. 129, no. 3, pp. 969-984, 2005.

[41] K. Boniface, E. Guignouard, N. Pedretti et al., "A role for T cellderived interleukin 22 in psoriatic skin inflammation," Clinical and Experimental Immunology, vol. 150, no. 3, pp. 407-415, 2007.

[42] Y. Zheng, D. M. Danilenko, P. Valdez et al., "Interleukin-22, a TH17 cytokine, mediates IL-23-induced dermal inflammation and acanthosis," Nature, vol. 445, no. 7128, pp. 648-651, 2007.

[43] M. Caproni, E. Antiga, L. Melani, W. Volpi, E. Del Bianco, and P. Fabbri, "Serum levels of IL-17 and IL-22 are reduced by etanercept, but not by acitretin, in patients with psoriasis: a randomized-controlled trial," Journal of Clinical Immunology, vol. 29, no. 2, pp. 210-214, 2009.

[44] A. Di Cesare, P. Di Meglio, and F. O. Nestle, "The IL-23Th17 axis in the immunopathogenesis of psoriasis," Journal of Investigative Dermatology, vol. 129, no. 6, pp. 1339-1350, 2009.

[45] B. Oppmann, R. Lesley, B. Blom et al., "Novel p19 protein engages IL-12p40 to form a cytokine, IL-23, with biological activities similar as well as distinct from IL-12," Immunity, vol. 13, no. 5, pp. 715-725, 2000.

[46] K. Boniface, B. Blom, Y.-J. Liu, and R. de Waal Malefyt, "From interleukin-23 to T-helper 17 cells: human T-helper cell differentiation revisited," Immunological Reviews, vol. 226, no. 1, pp. 132-146, 2008.

[47] E. G. Harper, C. Guo, H. Rizzo et al., "Th17 cytokines stimulate CCL20 expression in keratinocytes in vitro and in vivo: implications for psoriasis pathogenesis," Journal of Investigative Dermatology, vol. 129, no. 9, pp. 2175-2183, 2009.

[48] N. J. Wilson, K. Boniface, J. R. Chan et al., "Development, cytokine profile and function of human interleukin 17producing helper T cells," Nature Immunology, vol. 8, no. 9, pp. 950-957, 2007.

[49] L. C. Zaba, I. Cardinale, P. Gilleaudeau et al., "Amelioration of epidermal hyperplasia by TNF inhibition is associated with reduced Th17 responses," The Journal of Experimental Medicine, vol. 204, pp. 3183-3194, 2007.

[50] G. Tonel, C. Conrad, U. Laggner et al., "Cutting edge: a critical functional role for IL-23 in psoriasis," Journal of Immunology, vol. 185, no. 10, pp. 5688-5691, 2010.

[51] G. Piskin, R. M. R. Sylva-Steenland, J. D. Bos, and M. B. M. Teunissen, "In vitro and in situ expression of IL-23 by keratinocytes in healthy skin and psoriasis lesions: enhanced expression in psoriatic skin," Journal of Immunology, vol. 176, no. 3, pp. 1908-1915, 2006.

[52] J. R. Chan, W. Blumenschein, E. Murphy et al., "IL-23 stimulates epidermal hyperplasia via TNF and IL-20R2-dependent mechanisms with implications for psoriasis pathogenesis," The Journal of Experimental Medicine, vol. 203, no. 12, pp. 2577-2587, 2006.

[53] E. Lee, W. L. Trepicchio, J. L. Oestreicher et al., "Increased expression of interleukin 23 p19 and p40 in lesional skin of patients with psoriasis vulgaris," The Journal of Experimental Medicine, vol. 199, no. 1, pp. 125-130, 2004.

[54] K. C. Duffin, J. Woodcock, and G. G. Krueger, "Genetic variations associated with psoriasis and psoriatic arthritis found by genome-wide association," Dermatologic Therapy, vol. 23, no. 2, pp. 101-113, 2010.

[55] P. Di Meglio and F. O. Nestle, "The role of IL-23 in the immunopathogenesis of psoriasis," F1000 Biology Reports, vol. 2, no. 1, article 40, 2010. 
[56] L. Borska, C. Andrys, J. Krejsek et al., "Serum levels of the proinflammatory cytokine interleukin-12 and the anti-inflammatory cytokine interleukin-10 in patients with psoriasis treated by the Goeckerman regimen," International Journal of Dermatology, vol. 47, no. 8, pp. 800-805, 2008.

[57] C. T. Weaver, R. D. Hatton, P. R. Mangan, and L. E. Harrington, "IL-17 family cytokines and the expanding diversity of effector T cell lineages," Annual Review of Immunology, vol. 25, pp. 821852, 2007.

[58] S. Kagami, H. L. Rizzo, J. J. Lee, Y. Koguchi, and A. Blauvelt, "Circulating Th17, Th22, and Th1 cells are increased in psoriasis," Journal of Investigative Dermatology, vol. 130, no. 5, pp. 13731383, 2010.

[59] S. Matsushita and T. Higashi, "Human Th17 cell clones and natural immune responses," Allergology International, vol. 57, no. 2, pp. 135-140, 2008.

[60] M. A. Lowes, T. Kikuchi, J. Fuentes-Duculan et al., "Psoriasis vulgaris lesions contain discrete populations of Thl and Th17 T cells," Journal of Investigative Dermatology, vol. 128, no. 5, pp. 1207-1211, 2008. 


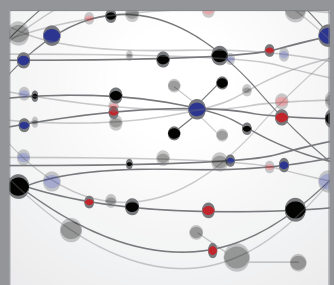

The Scientific World Journal
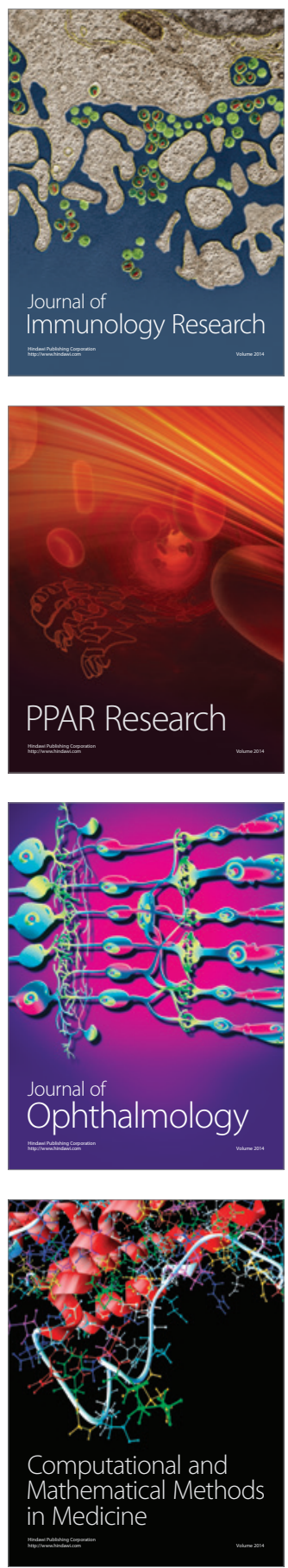

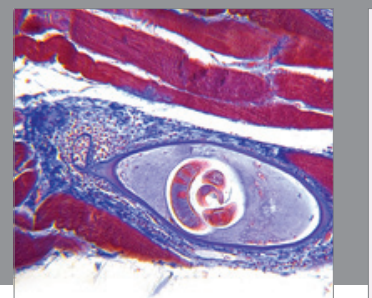

Gastroenterology

Research and Practice
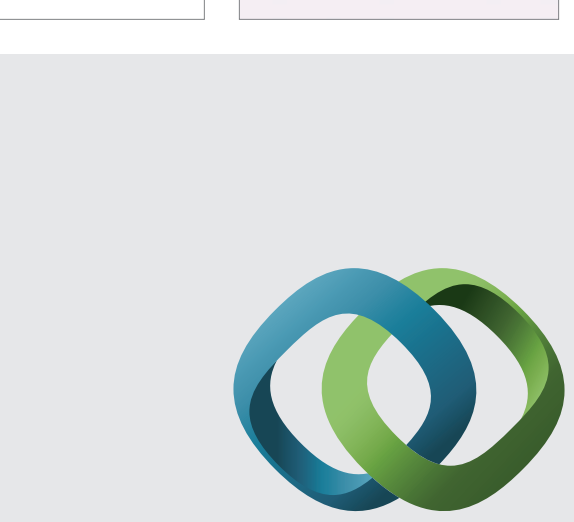

\section{Hindawi}

Submit your manuscripts at

http://www.hindawi.com
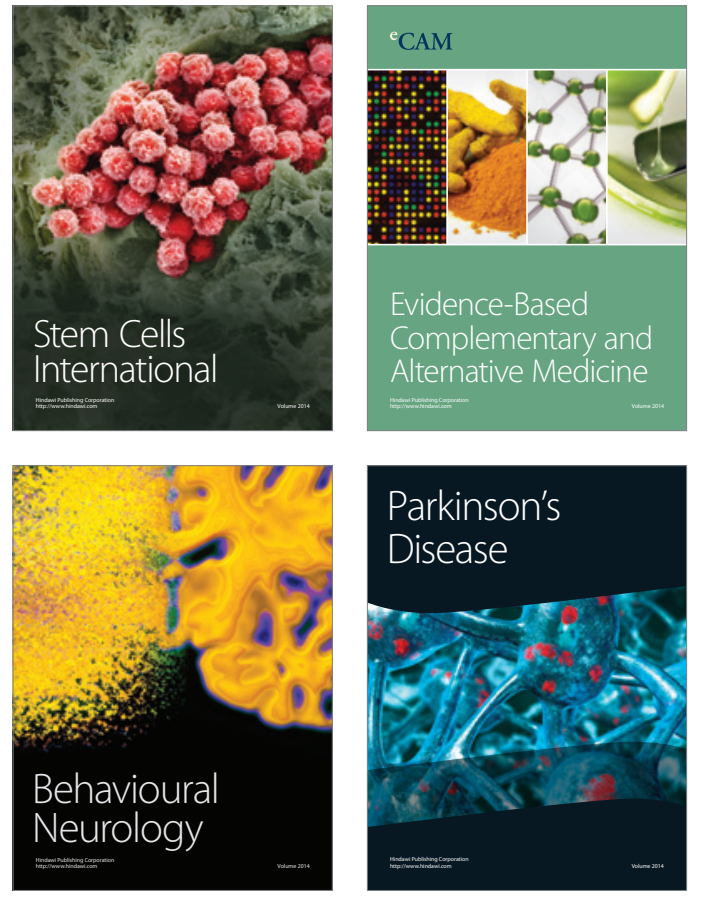
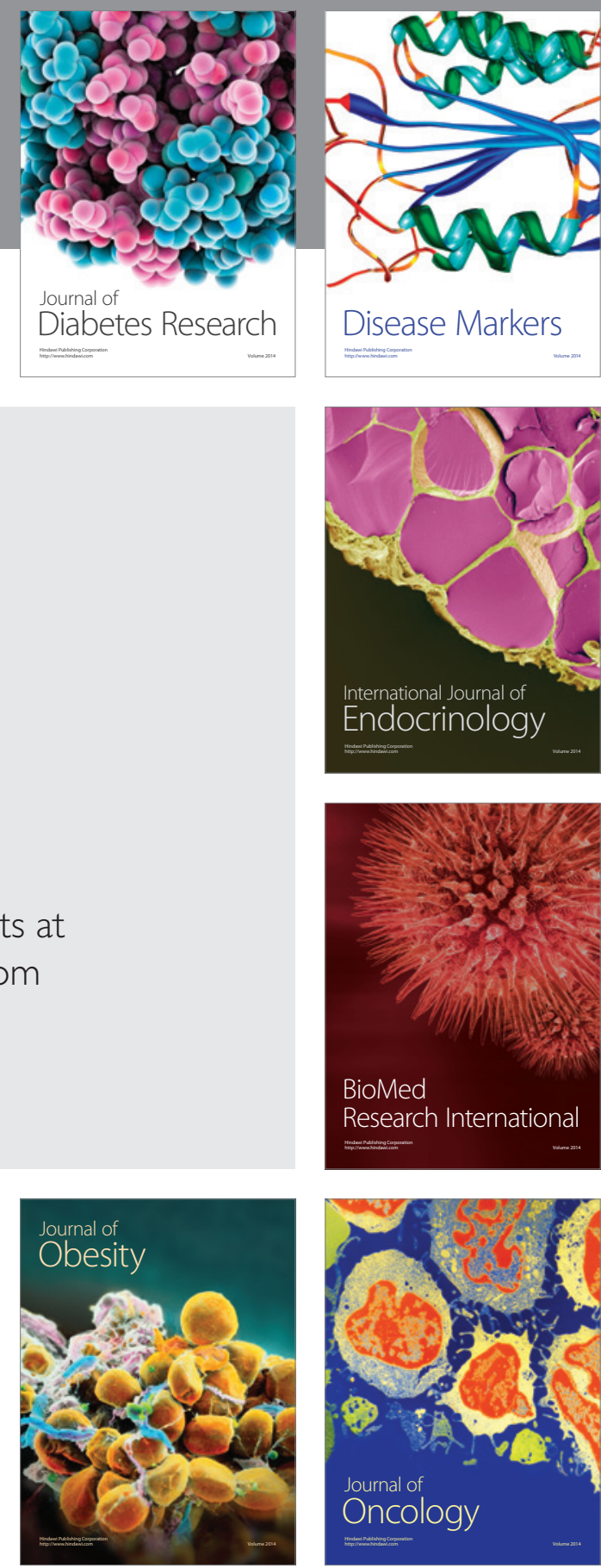

Disease Markers
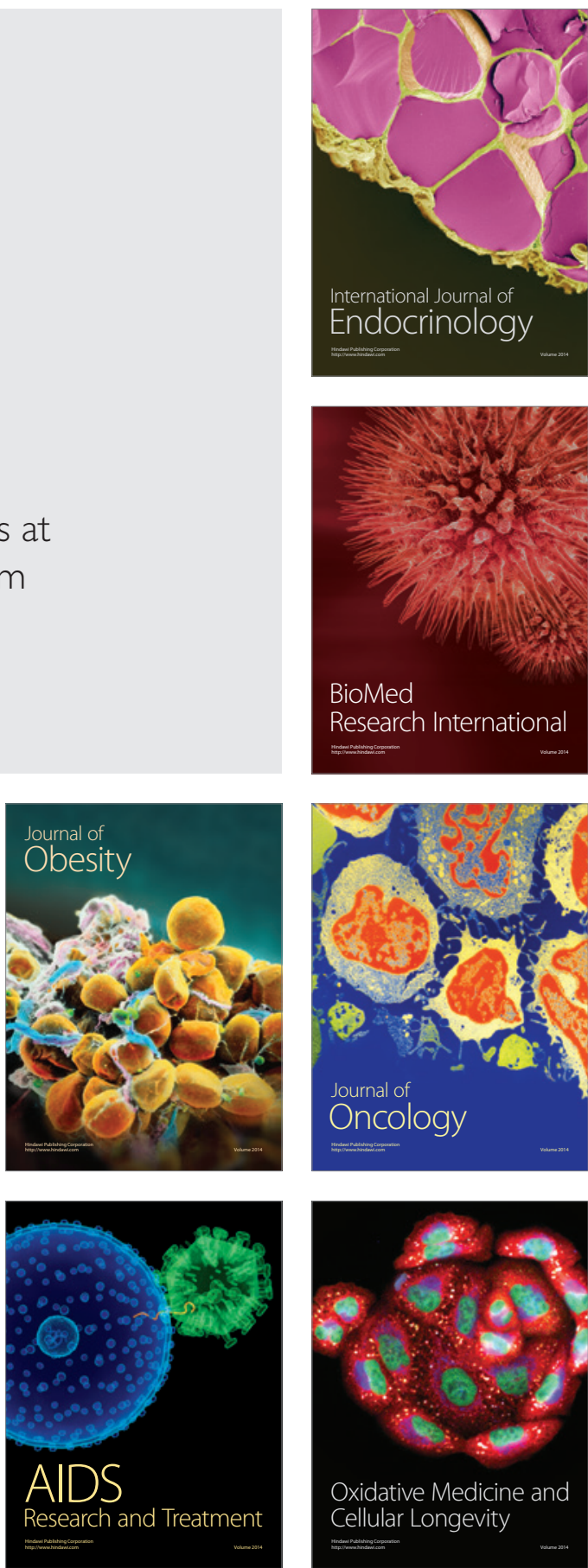